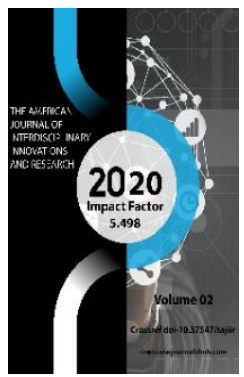

\title{
The Appearance Of Feature Films In The Life Of The Uzbek People As A Visual Tool Of Social Life
}

\author{
Ayupov Bahodir Rihsiboevich \\ Teacher Of The National Institute Of Fine Arts And Design Named After Kamoliddin Behzod, \\ Tashkent, Uzbekistan
}

Journal Website: http://usajournalshub.c om/index,php/tajiir

Copyright: Original content from this work may be used under the terms of the creative commons attributes 4.0 licence.

\section{ABSTRACT}

In the article, some facts are mentioned about the fact that the Soviet Bolshevik leadership attaches great importance to the art of cinema, actively uses cinematography to promote the ideology of Shura and integrate it into the consciousness of the people and does not spare anything for this purpose.

\section{KEYWORDS}

Cinematography, ideology, Bolshevik, idea, political spirituality

\section{INTRODUCTION}

Uzbek cinema has more than a century of history. Between these years, the era of production of silent black and white films to digital high-tech films began. Over the first decade of silent Uzbek cinema, more than a dozen films of various genres were created on a variety of topics: from marriage reforms to the socio-political situation, the promotion of women's rights and freedoms.

It goes without saying that this film cannot claim to be a high-level work, but today this film is acquiring new values. Its creators did not even hope for it. This value is only retained in the archived movie. From the point of view 
of a modern historian, films made during the silent period provide a large documentary material for the study of that period. For example, the image of the old streets of Tashkent in 1920-1930, as well as the original lyrics from the film "Ikkinchi khotin")("Second Wife")[10] are very important today in the homes of local residents, clothes, shoes, traditional crafts, embroidery, and decorations. According to press reports at the time, the film was well received by both the official critics and the general public. "Second Wife" Review Commission in Samarkand: "Second Wife" is a film taken from "inner" life and reflects real life ... artistic and technical performance can be called satisfactory. ......" [1].

Cultural processes in Uzbekistan in the $1920 \mathrm{~s}$ and 1950 s took place in a unique way, in the context of an acute struggle of agriculture, industry and society against the establishment of Soviet power, which was destroyed in the most difficult historical conditions. The Bolshevik leadership attached great importance to cinema. The main task of the rulers was to actively use cinema to promote Soviet ideology and its introduction into the minds of people, and they did not spare anything for this [2].

\section{MATERIALS AND METHODS}

Feature films began to appear in the life of the Uzbek people as an example of his work, as a means of reflecting the main problems of that time. The government of the republic thought about the equipment of the film factory. There was a narthex in the church, a floor where four small film crews could work at once. Various workshops have been created props, costumes, art workshops. Small rooms became rooms for these groups. A laboratory capable of handling 3000 meters of tape was also equipped, and equipment was purchased on an ongoing basis [3].
In 1922, V. I. Lenin, in a conversation with A. V. Lunacharsky about cinema, spoke about art cinema: "it should conduct artistic propaganda of our ideas in the form of interesting films depicting the life and implementing our ideas, these films should contribute to a wonderful, developing, refreshing mood before our country and form their ideas about foreign classes and foreign countries" $[4,5]$.

The decisions of the I and II congresses of the Communist Party of Uzbekistan emphasized that cinema should be "a powerful means of communist education and propaganda in the hands of the party"..., and film production should "resist any hostile classes of tendencies" $[4,5]$.

Although Uzbek cinema itself entered the artistic process in the republic a little later than other types of art, it immediately began to revive cinema. It should be noted that in the early years of the October coup, especially until the mid-1920s, there was some freedom in the activities of cultural and educational institutions where democratic principles were practised in public life. In addition, in the republics, they freely relate to national interests in relation to traditions and customs. The recognition of national identity gave a certain part of the population confidence in the policy of the Soviet state. Some intellectuals began to maintain the "humanitarian" character of the Soviet state. But by the mid-1920s, the situation in this area had changed. After the Soviet government gained political and moral superiority, it began to suppress the national and spiritual values of the people... [6]

The purpose of such a policy was to discriminate against the interests of national republics, suppress national republics on the basis of "helplessness", "illiteracy", falsely accuse them of nationalism, "create a Soviet 
culture", disguised by political myths, and form a single Soviet people.[4, 5]

In the result of the adoption on June 18, 1925, the Central Committee of the RCP (B.) "On Party Policy in the Field of Literature", the ideology of the influence of Marxism-Leninism is learned. The policy of salting began to penetrate constructively in all areas of art, including cinema. In order to ensure the development of cinema in accordance with socialist criteria, the state took it under its control, since it provided for the widespread use of cinema in the subordination of the masses to communist ideology. [7] Russian filmmakers, with experience, came to the aid of the national republics. Filmmakers who came to Uzbekistan at the invitation of his government did not have the same life and professional experience. [8]

Not all filmmakers who came to Uzbekistan understood their responsibilities. Some of them viewed their activities in Uzbekistan as a temporary period in their biographies. They did not enter the life of the Uzbek people, did not study its history and culture deeply. 19171925 years were the most active in the life of the Uzbek people. In 1923, the Bolsheviks founded "Turkdavkino" (State Cinema of Turkestan) to organize and use this art form for leadership and propaganda purposes, and its activities covered almost the entire territory of Central Asia [9]. Since the Bolsheviks tightly controlled the content of the films, both documentaries and feature films shot in the second half of the 1920s were mainly devoted to social and political events in the country.[3]

\section{CONCLUSION}

In conclusion, it should be noted that in the first moments of the appearance of the movie clock, we knew which way they would go. Of course, the film, which became an ideological propagandist, followed the path of the Soviet film school. Any society based on market relations is governed primarily by free market mechanisms. Fierce, healthy competition and long-term funding also served as a big push for the film to rise to the level of art and choose its own path of development. In the West, in particular, the development of the American film industry has also made the main goal of capital owners to make a lot of money by investing little in this kind of performing arts. In our case, it is better to be a means of managing society than a material interest.

\section{REFERENCES}

1. N.Karimova. (2016). "Igrovoi kinematograf Uzbekistana”. - p. 99.

2. Karimova, N. G. (2016). Dokumental'naya khronika pervykh kinematografov Bukhary. Teatr. Zhivopis'. Kino. Muzyka, (3).

3. Istoriya kul'tury Uzbekistana etapy, problemy, dostizhenie. (2016). Tashkent, p. 109.

4. Ungbaeva B.U. (1985). Politika ideologizatsii kinoiskusstva. $\mathrm{Na}$ materialakh istorii Uzbekistana. 19201930-kh gg. Kino Uzbekistana. Tashkent, p. 21.

5. Lenin, V. I. (1963). Samoe vazhnoe iz vsekh iskusstv: Lenin o kino. Sbornik dokumentov i materialov. Iskusstvo. p. 22.

6. Rezolyutsii i resheniya s"ezdov Kompartii UzSSR. (1957). Tashkent, Gosizdat UzSSR,. p. 39, 115.

7. Abul-Kasymova, Kh. (2008). Kino v sisteme zrelishchnykh iskusstv Uzbekistana. In Zrelishchnye iskusstva $v$ sisteme khudozhestvennoi kul'tury Uzbekistana KhKh veka. T. 1. 
8. Yusupalieva, D. K. (2016). Istorikosotsiologicheskii analiz razvitiya televideniya $\mathrm{v}$ Uzbekistane. Vestnik Chelyabinskogo gosudarstvennogo universiteta, (1 (383)).

9. Tsentral'nyi gosudarstvennyi arkhiv Respubliki Uzbekistan. №34-fond, p. 106.

10. “Ikkinchi khotin" 1927. Film authors: L. Seyfullina, V. Sobberey. Director: M. Doronin, Operator: V. Dobrzhanskii. 